\title{
Fiduciary Duty in Transitional Civil Law Jurisdictions Lessons from the Incomplete Law Theory ${ }^{1}$
}

\author{
Katharina Pistor \\ Columbia Law School \\ and \\ Chenggang $\mathrm{Xu}$ \\ London School of Economics
}

First Draft: October 2001

This Draft: March 2002

\begin{abstract}
:
In Anglo-American law, fiduciary duty is the core legal concept to address conflicts of interest of directors/managers and shareholders. The concept is developed and constantly refined by courts in the process of adjudication. By contrast, most civil law jurisdictions, including many transition economies, either lack the procedural rules that would enable parties to bring such cases to courts, or have not developed a sufficient body of case law to determine the contents and meaning of this concept. This paper asks, whether courts should be the primary lawmakers and law enforcers concerning the duty of loyalty. Based on our theory of the incompleteness of law, this paper argues that given a highly incomplete law, allocating lawmaking and law enforcement to courts is optimal when the expected harm does not have strong externalities. Breaching fiduciary duty is such an area, as "only" shareholders of that company, not the investing public at large will be harmed. While courts in transition economies may have difficulties living up to the task, we propose that for this particular area of the law, there are no better lawmaking and law enforcement mechanisms available. The case law they will produce is most likely to diverge from case law developed elsewhere, but this result is inevitable given incompleteness of law.
\end{abstract}

\footnotetext{
${ }^{1}$ We are indebted to Dimitri Gavriline, Moscow (Russia), and Professor Stanislaw Soltysinski, Warsaw (Poland) for locating relevant case laws; and to Dr. Tanja Buseva and Sinisa Petrovic of Croatia for trying to identify similar case laws in their countries.
} 
Introduction

Fiduciary duty is a core concept in Anglo-American corporate law for delineating the rights and responsibilities of directors and managers, as well as dominant shareholders vis-à-vis shareholders. Yet its precise meaning is difficult to discern without references to a large body of case law. Judge-made law has over time carved out a subset of specific obligations and standards of conduct associated with the principle. Most widely accepted are the duty of care and the duty of loyalty, where the duty of loyalty refers to situations in which conflict of interest is present. More recently, it has been proposed to add the duty of disclosure and the duty of special care when a company is a takeover target (Black 2001). The meaning of each of these obligations is explained by referring to a subset of more specific obligations derived by courts in the process of adjudication, with the important qualification that the enumeration of obligations is not exhaustive. Others can be added over time as business practices change and pose new challenges to the law.

The broad and encompassing nature of the concept appears to be a crucial factor in explaining the importance the concept has acquired in Anglo-American jurisdictions (Clark 1986; Coffee 1989; Eisenberg 2000; Johnson et al. 2000). It has allowed courts to take account of the changing nature of the business enterprise while maintaining at least the semblance of undisputed principles for determining what is right and what is wrong in corporate conduct. As many have pointed out, the corporate law of the U.S. in particular has developed from a (fairly) prohibitive, or mandatory, corporate law into an enabling one, which allows shareholders to opt out of many legal provisions and substitute them with their own contractually determined arrangements (Coffee 1989; Black and 
Kraakman 1996). The contrast with corporate law in many civil law jurisdictions is stark. German law, for example, explicitly states that all provisions of the corporate law are mandatory, except where otherwise stated. ${ }^{2}$ Still, in common law countries, courts have upheld the principles of fiduciary duty as the mandatory legal concept shareholders may not opt out of - a highly enabling corporate law not withstanding.

The same qualities that make the concept of fiduciary so resilient over time make it extremely difficult to transplant laws relevant to fiduciary duty from one legal system to other legal systems. The meaning of fiduciary duty is embedded knowledge that cannot be easily transplanted. Cases brought in different jurisdictions will differ and require different responses from judges, and given their past and constraints of their own legal system, judges in transplant countries are likely to resolve them differently.

The process of legal reform in transition economies so far has entailed primarily the transplantation of statutory law from Western European or US legal sources. Even when US law was taken as a model, the role of courts was kept at bay, as they were regarded as weak, incompetent or even corrupt (Black and Kraakman 1996). In this paper, we ask whether a superior mode of transplantation might be the copying of lawmaking and law enforcement mechanisms. We address this question drawing on our earlier work on the incompleteness of law (Pistor and Xu 2002a; Pistor and Xu 2002b). We argue that law is intrinsically incomplete, that is, the law cannot unambiguously stipulate all future harmful actions and associated degree of punishments. When law is incomplete, the effectiveness of law is contingent on how a legal system deals with the right to determine the content and meaning of incomplete law in the future, i.e. how it allocates the residual lawmaking and law enforcement rights. Allocating broad residual lawmaking rights to

\footnotetext{
${ }^{2}$ Compare Art. 23 Section V. of the Law on Joint Stock Companies (AktG).
} 
courts enables them to adapt the law over time to new cases as they arise. Our theory suggests that this allocation of residual lawmaking and law enforcement rights is optimal as long as the expected harm does not have externalities.

The effectiveness of the courts' residual lawmaking rights, of course, depends on the willingness of victims to bring cases to court, which in turn depends on the actual or perceived quality of the courts. If courts are weak, they may not be effective residual lawmakers and law enforcers, even if they are vested with extensive residual lawmaking rights. We argue that an ultimate solution to those problems is to strengthen the courts and attempts to circumvent the courts will not work.

We use statutory and case law from several jurisdictions, including two transition economies (Poland, and Russia) and one developed market economy (Germany) to identify the allocation of residual lawmaking and law enforcement rights, and to assess the ability of courts to address cases that were brought before them. A hallmark of all three jurisdictions is that case law is scarce (including in Germany). We attribute this to the failure of the legal system to clearly allocate residual lawmaking rights to courts. The scarcity of case law implies that courts by and large have little experience in dealing with cases that require a complex assessment of the rights and wrongs of corporate conduct. This lack of exposure may well account for the problems we identify in the decisions we analyze.

Part II: Theoretical Framework 
In this part of the paper we offer a theoretical framework for analyzing the role of courts in determining the contents of fiduciary duties and for exploring alternatives to judge made law in this area.

\section{Incompleteness of Law}

We suggest that law is intrinsically incomplete, because lawmakers are ex ante unable to foresee all future contingencies and specify solutions for them. A similar argument has been made in the economics literature with regards to contracts: parties to a contract cannot foresee all future contingencies and therefore cannot write a complete contract (Hart, 1995). A law is a grand social contract in that it attempts to offer legal guidance for future outcomes to unlimited future generations of citizens. In countries governed by the rule of law, law is purposefully designed to address a large number of cases and to last for long periods of time. The use of abstract language in statutory law is a means to ensure its generality. Even case law is made not only for the specific case at hand, but the court's ruling equally applies to other cases with a similar (not necessarily identical) factual basis (Ginsburg 1996).

If contractual parties cannot write complete contracts, lawmakers should be even less able to write complete laws. In fact, to write a - hypothetical - complete law, lawmakers would not only need unlimited foresight with regards to future events, but should be blessed with unbounded rationality. They would need to be able to anticipate the impact of the rules they make on all potential parties concerned and write rules that can achieve the first best results from a social welfare perspective. 
The notion that law is ambiguous or indeterminate has long been recognized in the legal literature (Hart 1961; Solum 1999). Thus, the claim that law is incomplete is not a novelty to most lawyers. What our theory seeks to add, however, is that in light of the incompleteness of law it is necessary to allocate residual lawmaking and law enforcement rights in order to ensure effective law enforcement.

The classic law and economics literature on law enforcement is based on Becker's groundbreaking work (Becker 1968; Polinsky and Shavell 2000). The intuition is that law is fully deters and thus is self-enforcing, if the level of punishment and the probability of being caught is designed to be sufficiently high. Stigler clarified that excessive punishment may not be optimal, but that the level of punishment should be optimally related to the level of violation (Stigler 1970). Then, at equilibrium, violations by rational players do not occur.

The implicit premise of this literature is that the law is complete and that all punishable actions are unambiguously stipulated in the law. ${ }^{3}$ Under this assumption, the major problem faced by a legal system is to design appropriate sanctions and to decide how much to spend on law enforcement so as to deter violation. ${ }^{4}$ If we relax this assumption and start from the premise that law is inherently incomplete, the deterrence effect of laws will be lowered and laws will not be self-enforcing. The reason is that under incomplete law the scope of applicability of the law becomes blurred. Given the

\footnotetext{
${ }^{3}$ While one may argue that this problem is captured by the probability of being caught, the incompleteness and enforcement probability issues are distinct. Incomplete law refers to the scenario that even if all evidence is established that someone committed a certain act, he may not be punished, because it is unclear whether the law actually captures that particular action. By contrast, the typical enforcement question is whether evidence can be established to convict a person or hold him liable under civil law assuming that the action is actually punishable.

${ }^{4}$ As Polinsky and Shavell (2000) show, the literature has addressed numerous related issues, including riskaverseness of agents, the possible impact of errors in the enforcement process, information costs, and the costs of enforcement. We ignore these aspects for the sake of clarity of the argument
} 
nature of law - laws are designed to address many and for long periods of time by lawmakers who cannot anticipate all socioeconomic and technological change - the reach of the law and its applicability to particular cases may be challenged or questioned. As a consequence, law cannot effectively deter.

Facing the problem of intrinsically incomplete law, lawmakers essentially have two options. First, lawmakers may establish a broad general norm, a catch-all clause that may be used to sanction actions that are not foreseeable at the time the law is made, but that might result in the type of outcome that the law seeks to prevent (Type I incompleteness). Type I incomplete law is similar to norms or standards, the terms that are commonly used in the legal literature (Kaplow 1992; Kaplow 1997). Second, lawmakers may attempt to capture as many contingencies as possible in statutory law. This type of law specifies actions, outcomes or a combination of actions and outcomes that will trigger liability and/or punishment and strives to be as comprehensive as possible (Type II incompleteness). Type II incomplete laws resemble rules in the conventional terminology.

There is also a third option. Given the difficulties involved in writing complete laws, lawmakers could dispense with lawmaking altogether and leave contractual parties to determine their relations by contract rather than law. In light of the fact that contracts are incomplete, however, this cannot be the end of the story. If we accept the notion that contracts are incomplete, all rights that are not explicitly contracted out, the so-called residual rights, need to be allocated. The holder of residual rights, the owner, has the right to decide issues not explicitly provided for in the contract. Yet the scope of these rights may be in dispute. Indeed, case law concerning property rights gives ample evidence that 
there is much demand for clarifying the scope of property rights (Komesar 2001). There is thus a need for a third party arbiter to determine the scope and contents of residual rights. The obvious authority for determining the delineation of residual and contractual rights is the law, not contracts, because the very existence of property rights is explained with the incompleteness of contracts. If, as we postulate, law is also incomplete, then the law's authority is not perfect. Nevertheless, by allocating residual lawmaking rights, legal systems can ensure that future questions can at least be addressed within a given legal framework.

The two strategies of lawmaking under incomplete law - writing open-ended standard or writing a very detailed law, or rule, aimed at encompassing as many contingencies as possible, will both produce incomplete law, albeit for different reasons. Broad legal standards create substantial uncertainties as to which actions will be considered a cause for liability or sanction, and which will not. For individual actors, this uncertainty could undermine the deterrence effect of the law, as they may gamble that their action will not be punished. The opposite outcome may also occur, as actors may be sufficiently deterred by the likelihood that their action could fall within the scope of the law. The point is that the uncertainty over the reach of the law renders it highly incomplete.

The concept of fiduciary duty discussed in this paper is an example of a law that is incomplete because it is broad and its scope is difficult to determine without referring to factual situations. We propose that such a broad, incomplete law can be made effective only by allocating residual lawmaking rights to the agent that is charged with enforcing the law. When the facts of the case are revealed, someone has to decide whether the relevant actions and outcomes were of the type the law sought to prevent. One may call 
this "interpretation" of the law, rather than lawmaking, but the action certainly entails more than only enforcement.

The second lawmaking strategy will result in incomplete law, because it is impossible for the law to include all future contingencies. Thus, there will always be cases outside the scope of the law. For all actions and/or outcomes that are captured by the law, the law will be easy to administer, and the law will give the appearance of being fairly complete. Still, for many actions, it will be questionable, whether they fall within the scope of that law, and others might be clearly outside its scope. Failure of the law to capture these cases implies that the law is incomplete. Type II incomplete law creates problems when confronted with substantial socioeconomic and or technological change. Absent such change, it may be possible to write highly complete law on the basis of the accumulated knowledge of typical actions that cause harm.

By the mid nineteenth century, for example, most legal systems had developed criminal law that could quite effectively deal with thieves who appropriated other peoples' property. After the invention and increasingly extensive use of electricity, the question arose, whether the unauthorized use of electricity would qualify as "stealing" electricity. Some courts denied this, because electricity lacked the asset quality required by the relevant theft provision, while others argued that the asset quality was less relevant than the ability to appropriate whatever the object of theft might be. Still other systems broadened the relevant theft provisions by including "theft of services" (Pistor and Xu 2002a).

In parallel to the incompleteness of contract literature, we call the right to deal with future contingencies of exiting law, i.e. the right to interpret the law, to apply it to 
different cases, and to establish new precedents, residual lawmaking rights. Residual lawmaking rights may be retained by the legislature. Alternatively, they may be vested with law enforcement agencies, such as courts, or regulators. The following section explores alternative allocations of residual lawmaking rights and their implication for the effectiveness of law enforcement.

2. The Allocation of Residual Lawmaking and Law Enforcement Rights

\section{Civil Law vs. Common Law}

It is clear that the principle of fiduciary is a highly incomplete legal principle that it is very general and is subject to many different interpretations. To ensure an effective enforcement of fiduciary duty, residual lawmaking and law enforcement (LMLE) rights must be allocated. We start our analysis from general difference of LMLE rights between civil law and common law countries.

Common law countries tend to vest substantial lawmaking rights with courts. Courts are explicitly acknowledged as a source of law and thus exercise not only residual, but also original lawmaking rights. ${ }^{5}$ In fact, the common law is primarily judge-made law. By contrast, civil law countries tend to vest less lawmaking rights with the courts. The official doctrine to this day is that judges interpret, but that they do not make the law.

It is now widely acknowledged that there is a substantial degree of convergence between the two systems, as courts in civil law countries have been called upon to adapt old laws to an ever changing world, and common law jurisdictions have over time made

\footnotetext{
${ }^{5}$ Original lawmaking rights imply the right to stipulate the principles of law, to write new rules, not only the right to interpret or adapt them.
} 
increasing use of statutory law (Zweigert and Kötz 1998). Nevertheless, it is probably fair to say that common law judges have and practice more extensive lawmaking rights than civil law judges.

By implication, civil law countries need to invest more resources into writing highly specific law, but still face the risk of under-enforcement should they fail to anticipate future actions that may result in substantial harm. Alternatively, they may complement reallocating residual lawmaking rights to different agents, such as regulators. Seen in this light, the widely held notion that civil law countries regulate more than common law countries (La Porta et al. 1999; Mahoney 2001) could be explained within the framework of our theory: Given the commitment not to allocate residual lawmaking rights to courts, civil law countries respond to under-enforcement problems by allocating these rights to administrative and regulatory bodies. By contrast, the broad residual lawmaking rights exercised judges in common law countries enjoy, ensure that potentially any dispute can be resolved in a court of law. Since the coverage of formal law and legal dispute resolution mechanisms is thus virtually complete, there may be less need for regulation unless there is a serious social need. ${ }^{6}$ Obviously, this proposition requires further substantiation. ${ }^{7}$

It is possible that in civil law countries judges assume greater lawmaking rights over time. In fact, German contract or tort law gives ample evidence of the ability of judges to

\footnotetext{
${ }^{6}$ In our parallel work we explain that this need arises when actions are likely to have a substantial impact on society as whole (not only on the parties they transact with). See (Pistor and Xu 2002a; Pistor and Xu 2002b).

${ }^{7}$ Indeed, there is substantial prima facie evidence to the contrary. Note, for example, that the US was the first country to establish an antitrust regulator (1914) and a federal securities market regulator (1933) and exported these models to civil law countries, such as Germany (antitrust) and Japan (antitrust and securities) after World War II.
} 
do so. ${ }^{8}$ Still, as long as the scope of the courts' lawmaking rights remains uncertain, this will influence the willingness of private parties to bring cases to court when it is unclear whether a court would hear a case or solve it, even when evidence can be established. It has been suggested that if the outcome of a court case is clearly predictable, parties will tend to settle out of court. ${ }^{9}$ However, from this does not follow that parties are willing to incur the costs of litigation whenever the outcome is uncertain. This is the case only, when courts have the residual lawmaking rights to deal with cases the outcome of which cannot be derived from looking at statutory or past case law, as there is at least hope that courts will resolve the case in the interest of the plaintiff. By contrast, when the scope of the courts' residual lawmaking rights is questionable, it may not be worth the expense to get the courts involved to begin with.

There may be good reasons for minimizing courts' residual lawmaking rights. This is true in particular in the context of a political and/or economic regime change, when countries confront the dilemma of having to deal with institutions and judges vested in the past while trying to change the overall system and behavior (Pistor 2000a). Judges appointed by the previous regime may be too politicized to be entrusted with the task of residual lawmaking rights in such an environment. This reasoning has certainly been invoked to explain the codification of law in France after the French Revolution (Cooter 1996; Glendon, Gordon, and Osakwe 1994). Transition economies today face an equally difficult problem. Replacing the judges in such cases is a difficult proposition, as this

\footnotetext{
${ }^{8}$ Courts have developed legal institutions that have no basis in the civil code, such as "culpa in contrahendo", "positive Vertragsverletzung", and have shifted the burden of proof to achieve stricter liability in tort cases, all in response to problems that were revealed by cases brought before them. ${ }^{9}$ (Priest and Klein 1984).
} 
might undermine the principle of judicial independence and could create moral hazard problems for establishing a truly independent judiciary in the future. ${ }^{10}$

In addition, judges may lack the training in new laws or even a basic understanding of the underpinnings of the new political or economic regime that is evolving. These considerations have led the drafters of the Russian corporate law to design a law that in their view would be self-enforcing (Black and Kraakman 1996). The strategy for building a self-enforcing law was to stress the importance of procedural over substantive rules. The hope was that by allocating decision-making rights to the parties in the corporate enterprise, in particular to shareholders, the need to involve judges in the enforcement of the law would be reduced.

While the model is intuitively attractive and generated much attention from policy advisors in emerging markets, in light of our incompleteness of law claim, it has serious limitations. A complete procedural rule would need to state unambiguously the procedural rights allocated to different parties. This is the easier task. It is fairly straightforward to determine which stakeholders have voting or approval rights, the right to request information, or to exit a firm. To be complete, however, the law would also need to state unambiguously the issues or events that will trigger these procedural rights. Given incompleteness of law, this is an impossible task. As a result, residual lawmaking rights need to be allocated to determine whether or not the facts of the case trigger the procedural rights that are stipulated in the law.

\footnotetext{
${ }^{10}$ This argument notwithstanding, a number of transition economies dismissed all judges and made the reappointment subject to some screening for their past conduct (lustration). Some jurisdictions, including the states of Saxony and Berlin in Eastern Germany, precluded judges who had enforced political criminal law from reappointment altogether. For an overview of these practices, see (Pistor 1995a).
} 


\section{Court vs. Regulators}

With respect to law enforcement, facing incomplete law a better solution might be to allocate residual lawmaking rights to other agencies rather than courts (Pistor and $\mathrm{Xu}$ 2002a; Pistor and Xu 2002b). We argue that in countries governed by the rule of law courts are designed to be neutral arbiters, impartial and subject only to the law. This implies that courts are only reactive law enforcers. Courts do not initiate enforcement proceedings, but have to wait until an action has been brought by aggrieved parties or by the state. By issuing a preliminary injunction, courts can enforce the law before harm has been done, but they cannot on their own behalf initiate proceedings for preliminary injunctions or final rulings. Giving courts the right to initiate legal proceedings would undermine their impartiality and turn them into regulators.

By contrast, regulators are proactive law enforcers. They can initiate legal procedures on their own and enforce the law by, among others, enjoining actions, controlling entry, and imposing sanctions for violations of rules even before harm has been done. The residual lawmaking rights allocated to regulators allow them to fine tune and flexibly change regulations in response to changes in the environment. The same features that make regulators effective law enforcer, however, create the danger of excessive state intervention.

The question, therefore, is not whether courts or regulators should be allocated residual lawmaking and law enforcement rights, but to define the conditions under which it may be advantageous to allocate regulators those rights. Glaeser, Johnson and Shleifer (2001) suggest that regulators are superior whenever costly investments are required from law enforcers, but it is difficult to induce them to make such investments. The thrust of 
their argument is that if collecting evidence in law enforcement is costly and law enforcers need to be given incentives, regulators are superior to courts, because they can be better incentivized through punishment and reward mechanisms.

According to our theory, the choice between regulators and courts depends on the degree of incompleteness and the severity of externalities that may result from harmful actions. Rapid socioeconomic and/or technological change, which renders law highly incomplete, paired with far reaching externalities that result from harmful actions make a case for shifting residual lawmaking and law enforcement rights from reactive to proactive enforcement institutions, i.e. from courts to regulators. By contrast, if individual actions do not generate great externalities, even when law is highly incomplete, allocating lawmaking and law enforcement rights to the courts is superior.

Law enforcement related to fiduciary duties is such an example. Fiduciary duties govern the relationship among stakeholders in a particular undertaking (i.e., management vs. shareholders, blockholders vs. minority shareholders). The harm done when these duties are violated is typically confined to the very same stakeholders. Reactive law enforcement can compensate those that have actually incurred damages. Law enforcement by regulators may not only not be necessary, but even harmful, because it is extremely difficult to stipulate ex ante the type of actions that may result in harm.

Allowing regulators to proactively enforce the law in these cases would likely result in excessive intervention in the operation of private businesses. As a result, not only can the direct cost of regulation be high without enhancing the effectiveness of law, the indirect costs as a result of misguided regulation can also be high. Therefore, reallocating residual lawmaking rights to regulators does not appear to be a viable solution. 
In contrast, financial market regulation is an area where the case can be made that lawmaking and law enforcement by regulators is superior. Financial markets evolve rapidly implying that law will almost always be highly incomplete in deterring actions that may result in harm. The expected harm may include a market crash, which damages confidence in market developments and thus undermines the proper functioning of financial markets. This harm is not easily undone, because compensation of few investors will not compensate for extern reinstall market confidence.

In the case of enforcing fiduciary duty principle, the most important effect of allocating lawmaking and law enforcement rights to courts is that related matters become justiciable, signaling that the relevant disputes can be resolved in law. This proposition is fully consistent with the finding of the studies by La Porta et al. (1997; 1998), which show that common law countries have less concentrated ownership than do civil law countries. From the vantage point of our theory we would interpret their evidence by saying that in civil law countries a legal vacuum is created by the absence of lawmaking and law enforcement rights vested with the courts. To protect their rights, investors therefore take larger stakes (Shleifer and Vishny 1997).

An interesting case to apply our framework to is the so-called Delaware puzzle. The puzzle is that companies incorporated in Delaware reveal higher market value than companies incorporated elsewhere in the U.S. (Daines 2001), despite the fact that the Delaware statutory law is rather weak in protecting shareholder rights (Arsht 1976; Cary 1976; Larcom 1937). In fact, Delaware statutory law is not a stellar performer on the scale of shareholder rights identified by La Porta et al. ${ }^{11}$ Several authors have already

\footnotetext{
${ }^{11}$ The 1-share-1-vote rule is only optional, shares can be blocked before the meeting; cumulative voting is only optional; preemptive rights require explicit recognition in the corporate charter. Delaware does,
} 
suggested that the solution for this puzzle lies in the function of the Delaware courts (Coffee 1989; Daines 2001; Fisch 2000). Our argument is similar. The fact that courts exercised lawmaking and law enforcement rights and that - perhaps because of the enabling nature of the corproate law - they were increasingly called upon to resolve disputes, they developed a large volume of cases law. In doing so they have made specified the meaning of the principle of fiduciary duty over time, or made the principle more complete. Given the higher level of completeness of the case (not the statutory) law, shareholders are better protected in Delaware than in other states that do no have an equally comprehensive body of law. The same argument would explain, why other states have not found it easy to emulate the Delaware example by simply copying her law, or even using Delaware case law as a guidance. When law is incomplete, judges play an important role in interpreting the law. Knowledge of the judges' previous approaches to case law and of the expertise of judges who specialize in a particular area of the law will make it easier investors and their attorneys to predict the outcome of a case and thus for them to bring a case to court, if necessary. Copying statutory or case law cannot replicate this.

\section{Alternative Legal Strategies}

Rather than searching for formal legal solution, it would be possible to leave broad areas outside the scope of formal law, as social norms may govern more effectively and a fewer costs (Bernstein 1992; Ellickson 1991). This applies also in the area of corporate law (Rock and Wachter 2001). However, the strength of these non-legal mechanisms 
depends at least in part on the available of recourse to the formal legal system, as many informal enforcement mechanisms operate in the shadow of the law (Charny 1990). We suggest that the power of the fiduciary duty principles rests on the fact that they offer an avenue to formal dispute settlement as an effective fall back option should non-legal enforcement mechanisms break down. Leaving these issues outside the formal legal system gives those that hold the de facto powers - i.e. incumbant management or blockholders - effective control rights (Pistor 1995b).

To summarize, our basic argument is that the principle of fiduciary is a highly incomplete legal principle (Type I incompleteness). To ensure effective law enforcement, residual lawmaking and law enforcement rights must be allocated. Since the actions that may violate fiduciary duty principles do not lend themselves well to standardization and the expected harm affects primarily the company's shareholders, not investors or society more broadly, residual lawmaking and reactive law enforcement by courts is optimal.

\section{Part III: Case Law From Civil Law Jurisdiction}

In this part, we analyze relevant case law using the theory summarized in the previous section. We focus on cases, which, in the Anglo-Saxon context, would be analyzed under the rubric of fiduciary duty. Conflict of interest cases (violation of the duty of loyalty) are of particular interest, because they pose a greater challenge to courts in differentiating acceptable from unacceptable behavior, but duty of care cases have also been included. ${ }^{12}$

\footnotetext{
${ }^{12}$ See the main Polish case presented below. A conflict of interest case was simply not available.
} 
In transition economies, case law is only emerging, and in many countries not a single case concerning the violation of fiduciary duty has been reported at the higher courts. Given the scarcity of case law, it is difficult to predict, whether the few cases that we have seen are indicative of future trends. At least, they allow us to take a glance at the evolving law.

The only non-transition country included is Germany. German law has long influenced the development of statutory civil and commercial law in Central and Eastern Europe (Pistor 2000b). It is therefore reasonable to assume that German case law may also gain influence in countries that borrowed German statutory law. In this sense, the analysis of German case law on fiduciary duty may hold important clues for the evolving case law in transition economies. But there is another, potentially more important, reason for including German case law in this analysis. While German courts for the most part follow the general doctrine prevalent in civil law jurisdictions that courts interpret, but that they do not make law, on occasion courts have used broad principles such as fairness, or even fiduciary duty, to correct results that would follow from a rigid application of statutory law. Given the relative scarcity of case law, however, it remains difficult to predict when they choose to do so. Litigants certainly are still cautious as evidenced by the fact that case law that recognized principles of fiduciary duty or gave shareholders better standing in courts were not followed by a flood of litigation. ${ }^{13}$ Thus, the German example give pause to think about the implication of withholding residual lawmaking rights from courts. It implies that courts will not be exposed to cases and thus

\footnotetext{
${ }^{13}$ The Holzmueller decision of the German Supreme Court of 1982 (BGHZ 83, 122) was widely expected to lead to a significant increase in litigation, because it recognized a procedural right of shareholders to sue when their rights are seriously infringed.
} 
cannot engage in a learning process themselves. Failure to explicitly allocate residual lawmaking rights thus results in path-dependent under-enforcement of law.

\section{Poland}

Poland recently enacted a new corporate law. ${ }^{14}$ Case law currently available rests on the Commercial Code (CC), which originally was enacted in 1933 and formed the basis for the evolving post-socialist corporate law. We therefore base the following analysis on the CC. The code included almost identical provisions on the liability of managers and directors in closed and publicly traded corporation. Art. $474 \mathrm{CC}$ on publicly traded corporations reads:

1. A member of the company's governing bodies and the liquidator are liable to the company for damage caused by their actions which are contrary to the law or the provisions in the Company Statute.

2. A member of the company's governing bodies and the liquidator are liable to the company for any damage caused as a result of their failure to exercise the care of a diligent trader.

The key issue is what is meant by "diligent trader", a term we would call a typical example of Type I incomplete law. ${ }^{15}$ No further specifications can be found in the law, leaving it ultimately to courts to decide this issue, provided, of course, that procedural rules exist ensure that management can be take to court in case it violates the duties of a "diligent trader". Sec. 474 explicitly states that directors are liable to the corporation, not to shareholders directly. In principle, the corporation must take action against members of the governing bodies. But the corporation would have to be represented by a governing

\footnotetext{
${ }^{14}$ The new Companies Act was adopted 15 September 2002 and entered into force 1 January 2001. A German translation of the Act can be found in (Breidenbach 2001).
} 
body, which would have to implicate itself (or one of its members), there are few incentives to bring actions. The old CC did, however, allow shareholders to bring an action on behalf of the corporation, if the corporation had failed to act itself for more than a year after having discovered the facts that give rise to liability claims (Sec. $477 \mathrm{CC}$ ).

Given these procedural constraints, it is perhaps not surprising that case law has been scarce. As of June 2001, only two decisions concerning the liability of directors in a closely held corporation have been reported. One concerned the extent to which a director could use mismanagement by the defendant as an excuse for his own misconduct - which was rejected. ${ }^{16}$ Another concerned the appropriate standards of responsibility, when the manager is concurrently an employee of the corporation. ${ }^{17}$ For publicly traded corporations, there has not been a single ruling by the Polish Supreme Court. We therefore report a 1998 decision of the Katowice Court of Appeal. ${ }^{18}$ The decision deals with the duty of care of members of the board of directors. No claim of conflict of interests was made.

The plaintiff was shareholder of the Bank Ślaski SA (the Bank). Defendants were members of the board of directors [management board] of the Bank. ${ }^{19}$ The bank was

\footnotetext{
${ }^{15}$ For a definition of "incompleteness of law", see below [].

${ }^{16}$ Supreme Court ruling IV CKN 117/00 of 9 May 2000: "It cannot be considered effective for a defendant to invoke the risk connected with carrying out a business activity as a reason to release him/her (according to the rules of contractual responsibility) from his/her liability towards a limited liability company based on Art. $292 \S 1$ of the CC when the harm is a result of the improper management by the defendant of the company's affairs. However, circumstances on the basis of which the harm could at most have been reversed are covered by risk."

${ }^{17}$ Supreme Court Ruling I PKN $482 / 99$ of 28 January 2000. In the case of an employee holding the position of member of the Management Board, while assessing his/her conduct as a serious infringement of the employee's basic duties (art. $52 \S 1$ point 1 of the Labor Law), his/her obligation to exercise the care of a diligent trader (Art. $292 \S 2$ of the CC) must be taken into account.

${ }^{18}$ I Aca 322/98, 5 November 1998.

${ }^{19}$ Under Polish law, a corporation may have a two-tier management structure, consisting of a management board and a supervisory board. See Art. 377 CC. A corporation with share capital of less than PLN 500,000 may choose between a supervisory board and an audit committee. Corporations that exceed the stipulated share capital must have a supervisory board.
} 
privatized in 1994. A special unit inside the Bank, a brokerage house with substantial organizational and financial independence, was charged with organizing the issuance of shares. The task to supervise the activities of the brokerage house was delegated to one member of the board. When shares were offered in the privatization process, they were heavily over-subscribed. The Bank was unprepared for the demand for shares. In particular, it failed to set up appropriate organizational structures inside the bank.

This failure constituted a violation of securities regulations and the Bank was indeed fined by the Polish Securities and Exchange Commission (KPWiG). The member of the board that had been in charge of supervising the issuance of shares was fired. In the case brought before the court, the plaintiff (a shareholder) demands that other members of the board reimburse the bank for the fine it had paid to the KPWiG. The defendants argue that they had fulfilled their obligations under the law by delegating the task of supervising the share issuance to one of their members and therefore were not liable.

The court of first instance denied a course of action. Upon the plaintiff's appeal, the Katowice Court of Appeal reversed the decision. The official summary of the court ruling states:

"The care of a diligent trader should include: foreseeing the results of planned actions, undertaking all possible factual or legal measures in order to fulfill the obligation undertaken, showing foresight, conscientiousness, carefulness and care in order to achieve the results in accordance with the company's interests. A large degree of independence of a brokerage house and its financial and organizational separation, which allowed it to make decisions by itself, did not exclude it from the supervision of the bank, and the manager of the office was appointed and dismissed by the bank's management board. To designate one of the members of the bank's management board to supervise the activities of the brokerage house should normally not release the remaining management board members' from their responsibility in this respect." 20

\footnotetext{
${ }^{20}$ The translation of the summary was provided by Prof. Soltysynski.
} 
Essentially, the court replaced one highly incomplete term with a set of others sufficiently broad to be used to hold members of the governing bodies of the corporation liable for virtually any conduct that ultimately results in harm. After all, the wording the court used suggests that they are required to undertake all possible factual or legal measures to further the interests of the corporation. This ruling will therefore be of little guidance for managers and lower courts alike when determining in future case law, which actions - or failures to take action - should result in legal liability. In fact, as stated, it may deter risk taking on the one hand, and organizational means as those taken by Bank Ślaski SA, on the other, if such measures will not restrict the liability of board members.

The decision documents a lack of experience with corporate decision making processes and reluctance by the court to develop criteria to delineating actions that should result in personal liability from those that should not. In light of the fact that common law courts have taken many decades to develop a body of case law, this may not be surprising. The point is that transition economies need to catch up fast to address the subtler problems of corporate governance. Procedural rules that make it difficult to bring court actions, do not facilitate this learning process. A possible solution could be to carve out aspects of fiduciary duty that lend themselves to greater specification in the law. This attempt has been tried in Russia, as will be discussed in the following section.

\section{Russia}

Russia enacted its law on joint stock companies in 1996. The law is based on a draft developed with by American legal experts, including Professors Black and Kraakman (Black and Kraakman 1996; Black, Kraakman, and Hay 1996). While it has many traces 
of American corporate law, it is not a simple copy. Instead, the authors sought to create a new type of corporate law, one that would rest primarily on procedural rather than substantive provisions to ensure that shareholders could self-enforce the law and would not have to rely on courts that are depicted as slow, incompetent, and corrupt. The law avoids broad encompassing concepts and instead attempts to spell out the rights and obligations of shareholders and directors in great detail. The law does not codify the principle of fiduciary duty. An explanation that has been put forward is that Russian language does not have words that would adequately capture the concept (Black, Kraakman, and Tarassova 2000) - which may be taken as an important indicator that the very concept of fiduciary relationships, and not only the law, is not well developed.

Another reason is that the law purports to educate shareholders, managers, and the public about corporate conduct and therefore favors specificity over generality. Finally, Russian lawmakers may have been wary to include broad provisions that would vest courts with substantial residual lawmaking rights. ${ }^{21}$

As in Poland, case law is only emerging. Until 1998, cases that reached the Supreme Arbitrazh Court (SAC) in Moscow were still based on the old corporate law. In the majority of cases concerning violations of shareholder rights the corporations brought actions demanding to void contracts that had been entered into in violation of provisions that required approval by all members of the board or the shareholder meeting. It appears that litigation was thus used strategically for the company to escape contractual liability, not for shareholders to enforce their rights (Kursynsky-Singer 1999).

\footnotetext{
${ }^{21}$ In fact, Professor Black, one of the co-drafters of the law suggested that the legislature eliminated references to broader judicial power in an earlier draft.
} 
The new corporate law carved out certain aspects of the fiduciary, namely

transactions in which a director or one of his affiliates has an interest. The law defines factors that suggest an "interest", establishes procedures for approving transactions should there be a conflict, and stipulates that violations of these rules lead to liability of the relevant persons vis-à-vis the company or to voidance of the transactions.

Art. 71 of the 1996 Russian Law on Joint Stock Companies (JSCL) states in section 1 that

“The members of a company's board of directors (supervisory board), the company's individual executive organ (director, general director) and (or) members of the company's collegial executive organ (managing board, directorate) and equally the managing organization or manager when exercising their rights and fulfilling their duties must act in the interest of the company, exercising their rights and fulfilling their duties with regard to the company in good faith and reasonable". 22

The SAC has not had an opportunity yet to determine the meaning of good faith and reasonableness. However, it has dealt already with a several cases concerning violations of conflict of interest. The legal basis for these cases can be found in Arts. 81-84 JSCL. ${ }^{23}$ The fact that legal provisions that stipulate in substantial detail actions that may give rise to liability resulted in litigation, while provisions that establish management obligations in broad, ambiguous terms have not, is an interesting point to note. It supports our claim that if the scope of the courts' residual lawmaking rights is ill-defined, potential litigants will be reluctant to incur the costs of litigation.

\footnotetext{
${ }^{22}$ For this and the following excerpts from the law, the English language translation by Black and Tarassova in (Black, Kraakman, and Tarassova 1998) was used.

${ }^{23}$ Several U.S. jurisdictions have also codified conflict of interest situations. See Delaware General Corporate Law $\S 144$. Note, however, that the Delaware law precludes the voidance or voidability of transactions concluded by interested directors, if their interest was disclosed and the transaction was overall "fair" - introducing another broad concept that requires fine-tuning by case law. For a much more detailed elaboration on conditions that lead to a conflict of interest, see $\S 8.60-8.63$ of the Revised Model Business Corporation Act.
} 
Art. 81 defines an interest in a company's completion of a transaction. The relevant persons who might have an interest include the members of the board(s), or shareholder(s) holding together with affiliated person(s) 20 or more percent of the company's voting shares. An interest exists, if these persons, their spouses, parents, children, brothers, sisters, and all their affiliated persons

- $\quad$ Are a party to this transaction or participate in it in the capacity of representative or intermediary;

- $\quad$ possess 20 or more percent of the voting shares (participatory shares, units) of a juridical person that is a party to the transaction or participates in it in the capacity of representative or intermediary;

- occupies an official position in the management organs of a juridical person that is a party to the transaction or participates in it in the capacity of representative or intermediary.

The effort to write a highly complete law notwithstanding, the conditions that indicate an interest all contain terms and concepts that require further interpretation, or are incomplete. For example, they require that someone must act "in the capacity of representative or intermediary." They do not simply stipulate "the general director" or "a member of the board", anticipating that others may be acting as agents of the corporation and thus could find themselves in a conflict of interest situation. Thus, while the general attempt is to write Type II incomplete law, many of the terms used contain elements of Type I incompleteness.

The interested person must disclose her interest to the supervisory board, inspection commission and auditors. Transactions that are affected by an interest must be approved by a majority vote of the company's disinterested directors. In case the company has more than 1,000 shareholders, the directors making the decision must be both 
disinterested and independent. ${ }^{24}$ Moreover, it must be established that the value the company will receive for property alienated or services delivered does not exceed market value, or - conversely - that the value of the property acquired or services accepted is not below market value. $^{25}$

A decision by the disinterested and/or independent directors is not sufficient in all cases. Whenever the total payment in the transaction and the value of the property that is the subject of the transaction (...) exceeds two percent of the company's assets, or when the transaction and (or) several transactions interrelated among themselves consists of issuance of voting shares of the company or other securities convertible into voting shares, in an amount exceeding two percent of the company's previously issued voting shares, the decision shall be taken by the Shareholder Meeting. Exceptions to this rule include a loan given by the interested person to the company, or cases where the transaction is completed

"in the process of ordinary economic activity between the company and another party, which had been in place before the moment after which the interested person is deemed to be interested".

\footnotetext{
${ }^{24}$ An independent director is defined as "a member of the company's board of directors (supervisory board) who is not the company's individual executive organ (director, general director) or a member of the company's collegial executive organ (managing board, directorate), if during this his spouse, parents, children brothers, and sisters are not persons occupying official positions in the company's management organs." Art. 83 Section 2 para 2 JSCLruss.

${ }^{25}$ See Art. 83 Section 2 para 3. The provision makes explicit reference to Art. 77 of the JSCL, which explains how to determine market value in an economy that is still in transition from a centrally planned economy: "The market value of property, including the value of a company's shares or other securities, is the price at which a seller having full information about the value of the property and not obliged to sell, would agree to sell it, and a buyer having full information about the value of the property and not obliged to acquire the property would agree to acquire it" (Art. 77 JSCL). The law goes on to say that the market value is determined by the company's board of directors (supervisory board).
} 
Violations of the above provisions have two legal consequences. First, the transaction may be deemed void (Art. 84 Sec. 1). Second, the interested person is liable to the company for the amount of losses that he caused to the company (Art. 84 Sec. 2) ${ }^{26}$

An action for the invalidation of contracts can be filed by shareholders as well as by the parties to the transaction, i.e. the corporation that was represented by the person who had an interest, as well as the other party. The SAC had to clarify that organizations that were not a party to the transaction, including the company's creditors, had no right to file for invalidation of such transactions. ${ }^{27}$

An interesting feature of the Russian legal system is that even in what appears to be a private law matter, a state agent may get involved and either bring an action or launch an appeal against a court decision. This agent is the so-called procuracy, an institution that dates back to the time of Peter the Great (Butler 1988). The procuracy has a mandate to ensure legality and to safeguard public interest. The relevant statute states that the procurator has the right to apply to court with a statement or to get involved in a case at whatever stage of the process, if that is required to protect the rights of citizens, the interests of society, or the state. ${ }^{28}$ Moreover, the Arbitration Procedure Code explicitly refers to the procurator's right to lodge a civil suit to protect the interests of state and society.

Within our framework, the procurator is an institution that resembles a regulator in that it can initiate legal actions. Unlike regulators, however, procurators do not take part in lawmaking activities. There are examples for similar institutions in Western legal

\footnotetext{
${ }^{26}$ In other words, Russia combines the liability with the property rule. For the distinction of self-dealing rules and their legal consequences along these lines, see (Goshen 2001).

${ }^{27}$ Ibid under 17 at $\mathrm{p}$. [].

${ }^{28}$ Art. 3 of the Federal Law on the Procurator's Office of the Russian Federation.
} 
systems. Under the U.S. Sherman Act of 1890, the Department of Justice (its attorneys) was given the right to bring criminal or civil actions against violators of the Act. Similarly, apart from launching investigations, the SEC can initiate legal proceedings in court against legal violators. The main difference is the broad, ambiguously defined powers of the procurator to bring actions to protect the interests of state and society. This is clearly an incomplete term, and one that gives the procurator substantial discretion in intervening in private affairs. While it is ultimately up to the courts to decide on the merits of such actions, it is questionable, whether a state initiation agent with such sweeping powers is desirable. From a law enforcement perspective, the answer could be yes based on the grounds that such an institution can greatly enhance enforcement. Still, there is the danger of over-deterrence both of the transactions that are challenged in court and of bringing a case to court. As we argued above, the reallocation of the right to initiate actions from private parties to state agents should therefore be limited to cases where the failure to initiate proceedings may result in substantial harm to others beyond the immediate parties to the transaction.

Cases where the procurator initiated a lawsuit on the grounds that management violated its obligations towards shareholders have not been reported. In a recent survey of judicial practice concerning the conflict of interest provisions of the JSCL, the SAC summarizes the legal issues that arose in case law. ${ }^{29}$ In all cases the legal remedy sought was voidance of the contract rather than liability of the interested persons. In contrast to the case law brought under the previous law, however, not all cases were brought by the

\footnotetext{
${ }^{29}$ Obsor praktiki pazrescheniia sporov, sviazannykh s zakliucheniem khoziaistvennymi obschestvami krupnykh sdelok i sdelok, v soverschenii kotorykh imeetcia zainteresovannost' (Survey of practical decisions of disputes related to the conclusion of major transactions and transactions affected by conflict of
} 
corporation, but several cases were filed by disgruntled shareholders. The fact that they sued for voidance rather than compensation requires a different explanation. A possible one is that the law clearly stipulates that violations of conflict of interest provision result in liability vis-à-vis the corporation, not the shareholders, and Russian law does not provide for derivative action. Thus, it is unclear whether shareholders would indeed have standing if they sued for damages (Black, Kraakman, and Tarassova 1998).

Several decisions addressed the issue whether an interested person was in fact a party to a transaction, or a representative of that party. Thus, the decisions had to address precisely the ambiguities left in the law. It was disputed, for example, whether a director who bought shares of "his" company had "an interest" when he was buying the shares from an underwriter rather than directly from the company. The court rejected the argument on the grounds that the underwriter acted on behalf of the company rather than as an independent agent and voided the contract. ${ }^{30}$

In another case ${ }^{31}$, Informenergo and Gala-Inform entered into a contract over parts of a building, the value of which exceeded two percent of Informenergo's assets. Thus, approval by the Shareholder Meeting was required..$^{32}$ The general director of Informenergo had an interest in the transaction by virtue of the fact that he - together with other affiliates - held over twenty percent of the stock in Gala-Inform. ${ }^{33}$ The lower court denied the action brought by Informenergo to void the contract. It held that because the general director had authorized a third person to sign the contract on behalf of

interest). Information Letter of 13 march 2001 No. 62 published in Vestnik Vyshevo Arbitrazhnogo Suda Rossiiskoi Federatsii No. 7 (2001), pp. 72,79 (hereinafter Information Letter No. 62).

${ }^{30}$ Information Letter op. cit at p. 79.

${ }_{32}^{31}$ Presidium Supreme Arbitrazh Court, 27 July 2000 (No. 8342/99).

${ }^{32}$ See Art. 83 JSCL. 
Informenergo, the director himself was neither a party nor acted as a representative, and thus a conflict of interest situation did not exist. The SAC reversed, explaining that the delegation of the power to sign the contract on behalf of the company did not eliminate the conflict of interest situation.

Other cases addressed the question, whether a conflict of interest provisions could affect a transaction concluded after the conflict of interest situation had been eliminated or before it came about. In one case, the plaintiff, a close corporation, had acquired shares in a joint stock company. The general director of the joint stock company was a cofounder of the plaintiff, holding $20 \%$ of its stock. He sold that stake prior to the transaction in question. The court ruled that because the conflict of interest situation must exist at the time the transaction is concluded, there was no violation. The SAC explicitly stated that "by virtue of Article 81 of the Law on Joint Stock Companies,, an interest in the transaction has to be ascertained at the time it is entered into." 34

In a separate case, a joint stock company concluded a contract to acquire goods from another corporation. The value of the transaction exceeded two percent of the corporation's assets. Within a month after entering into the agreement, the plaintiff's general director acquired a stake of 20 percent in the seller's company. The court held that in these circumstances approval by the shareholder meeting was not necessary. The transaction was within the realm of ordinary business transactions and the conflict of interest situation arose only after the transaction had already been concluded.

\footnotetext{
${ }^{33}$ The general director held $40 \%$ in AOZT Flesch-Invest, which in turn held 50\% in OOO Flesch and 50\% in Flesch-Market. Flesch Market held 50\% in OOO Tovarischestvo Flesch, which is the sole founder of Gala-Inform.

${ }^{34}$ Information Letter op. cit at p. 80.
} 
Existing case law reveals that courts are still struggling with recognizing conflict of interest situations as such or denying legal remedies where there is no clear conflict of interest. Take, for example, the following case, in which a company demanded from its bank to carry out a transaction in foreign currencies. The bank refused to follow the order on the grounds that it violated conflict of interest provisions, because the bank customer was also a major shareholder in the bank. A lower court in fact invalidated the decision, but was reversed by the SAC. The latter argued that the transaction was in compliance with banking and currency regulations and that the bank had no right to refuse to execute the order. The ownership relations were regarded as immaterial for this decision. ${ }^{35}$

In part, Russian case law can be blamed for deficient legislation. In fact, commentators have pointed out even before case law emerged that the law would give rise to ambiguities (Black, Kraakman, and Tarassova 1998). But this is only part of the story. Even the best designed law cannot stipulate all future contingencies unambiguously, and legislating actions that by their vary nature are hard to capture in clear cut statutory provisions will inevitably result in incomplete law.

\section{Germany}

German corporate law is highly detailed and most provisions in the law are mandatory, meaning that they cannot be changed by shareholder agreement. Case law is very limited, mostly because of the high threshold the law establishes for shareholder suits and the denial of derivative action. The one procedural remedy the law does allow, the challenging of the validity of decisions taken at the shareholder meeting in court, has been used quite extensively, and in the eyes of many observers, even excessively.

\footnotetext{
${ }^{35}$ Information Letter No. 62 at p. 82.
} 
The high level of specificity of the law and the absence of procedural rules to bring cases can be interpreted within our framework was a Type II incomplete law. Rather than allocating residual lawmaking rights to deal with future contingencies, the law seeks to precisely regulate those issues it anticipated at the time the law was drafted or amended. Inevitably, the result was incomplete law (Type II). Given the absence of procedural rules, which precluded courts from taking up a more active role as residual lawmakers, this resulted in serious under-enforcement.

The corporate law subjects management to the standards of a diligent entrepreneur. ${ }^{36}$ Several provisions further prohibit members of the board from competing directly or indirectly with the corporation, ${ }^{37}$ and subject credit contracts between them and the corporation to the approval of the supervisory board. ${ }^{38}$ These provisions have been interpreted as statutory specifications of the general duty of loyalty (Hopt and Wiedemann 1992; Hueffer 1995). In theory, this provision could have served as a focal point for courts to develop principles of corporate conduct similar to the case law that evolved in common law jurisdictions under fiduciary duties. Given the lack of procedural support, however, a body of case law never developed, even after courts extended procedural support by way of case law. ${ }^{39}$

Still, in several cases, courts have developed basic principles concerning the duty of loyalty for managers and have extended these principles first to blockholders and subsequently to minority shareholders. At first courts were reluctant to accept the notion that in a corporation directors owed fiduciary duties to shareholders. Such duties were

\footnotetext{
${ }^{36} \S 93$ Aktienggesetz (AktG).

${ }^{37} \S 88$ AktG.

38 § 89 AktG.

${ }^{39}$ Holzmueller Decision. BGHZ 83, 122.
} 
recognized only in highly personal relations, such as partnerships or employee relationships, where the additional feature of dependence led to the recognition of a duty of loyalty (Treuepflicht) already in the nineteenth century (Wellenhofer-Klein 2000). Only in 1975 did the German Supreme Court (BGH) recognize such a duty for closed corporation, ${ }^{40}$ and extended the application to joint stock companies in $1988 .{ }^{41}$

In the relevant case, Linotype, a minority shareholder challenged a decision to liquidate the company taken at the shareholder meeting with the votes of the only majority shareholder. The undisputed purpose of this decision was that the majority shareholder wished to integrate some operations of the company into his own company, but could not achieve this by way of merger, because under the law this required the consent of all shareholders. ${ }^{42}$ Prior to the shareholder meeting, the majority shareholder had already convened with the management board and discussed the details of the transaction, including the value of the assets that were to be transferred. The court held that the majority shareholder violated his duty of loyalty vis-à-vis the minority shareholders by discussing these issues without giving the minority shareholders a chance to participate or to take actions to acquire the company or its assets. ${ }^{43}$

At the core of the recognition of the duty of loyalty for corporations was the notion that directors and possibly other stakeholders may be in a position to exercise substantial control, the corollary of which is the duty of loyalty. By 1995 , this duty was extended to minority shareholders who had a veto right over a decision that determined the very

\footnotetext{
${ }^{40}$ ITT-Decision, BGHZ 65, 15 (1975).

${ }^{41}$ Linotype decision, BGHZ 103, 184 (1988)

${ }^{42}$ Note that the transfer of assets has been a common strategy to circumvent the overtly rigid requirements of unanimous decisions for approving a merger. $\S 65$ Umwandlungsgesetz (Transformation Law) passed in 1995 requires a qualified majority of $3 / 4$. Corporate statutes may stipulate higher majority requirements.

${ }^{43}$ The court actually referred the matter back to the court of appeal for further investigation on this point.
} 
existence of the corporation. In the Girmes case, the court ruled that the exercise of veto power by minority shareholders at a shareholder meeting, which blocked a decision that might have saved the company from liquidation, constituted a breach of their fiduciary duty vis-à-vis other shareholders. ${ }^{44}$ When the Girmes corporation became insolvent, a shareholder meeting was convened to decide on a decrease in corporate capital with a ratio of $5: 2$. The editor of a shareholder rights journal obtained proxies from minority shareholders to block this decision, arguing that a ratio of 5:3 would still safe the company without diluting minority shareholders as much. Because an agreement could not be reached, the refinancing arrangement failed and the company soon entered into bankruptcy proceedings. Shareholders voting with the majority took the matter to court. They sought damages for the loss of their stakes in the corporation, arguing that if the change in corporate capital had been implemented, the company would not have been bankrupted. ${ }^{45}$ The court held in favor of the majority shareholders. Because shareholders owe each other fiduciary duties, they are not entitled to block decision for selfish motives, especially when the very existence of the corporation is at stake. The court accepted the majority shareholders' view that creditors would not have accepted any other outcome of the shareholder meeting than the one they supported. ${ }^{46}$

An important implication of these cases is not only that courts used the principle of the duty of loyalty to limit the powers of directors or other stakeholders (WellenhoferKlein 2000), but that they employed a broad legal principle (Type I incomplete law) to

\footnotetext{
${ }^{44}$ Girmes Decision, BGHZ 129, 136 (1995).

${ }^{45}$ The lawsuit was actually filed against the editor that voted the proxies, because he refused to disclose the identity of shareholders that had given him the proxy. The court ruled in favor of the majority shareholders. Although the corporate fiduciary duties did not directly apply to the editor, who was not a shareholder, but held him liable under agency law for his refusal to disclose the principals he was representing.

${ }^{46}$ The decision has been widely accepted among legal scholars. See (Timm 1991) and (Dreher 1993).
} 
correct for a rigid statutory law. In Linotype, the duty of loyalty was used to assess strategies that were designed to circumvent a unanimous vote on the winding up of the corporation. In Girmes, it was applied to mitigate the powers that flowed from the supermajority requirements for changes in corporate capital imposed by the law. The irony is that while the concept of fiduciary duty has been used in the U.S. as the ultimate bastion of shareholders rights against the backdrop of a highly permissive corporate law, in civil law countries, such as Germany, it is used to balance a highly rigid mandatory law. The lesson seems to be that statutory law is inept to regulate in much detail the complex relation among key stakeholders in the corporation, which require a careful balancing act that is best left with the courts (Hüffer 1990).

Our analysis of the German case law is consistent with a study by Johnson et al. (2000) who examine how courts in French civil law countries have dealt with cases in which corporate insiders used their position to transfer corporate assets either directly to themselves or to another company they control (tunneling). They point out that clear, rigid statutory rules may invite strategies that conform to the letter of the law, but dilute corporate assets in their own favor. By contrast, the notion of fairness embedded in fiduciary duty allows courts in common law countries to assess the entire transaction. As the authors note,

"precisely because the common law notion of fiduciary duty is associated with a high level of judicial discretion to assess the terms of transactions and to make rules, it is at odds with the civil law emphasis on legal certainty.".

Using our framework of the incompleteness of law, we make a similar point arguing that when it is not possible to identify ex ante the type of actions that will amount to a violation of the law (i.e. and action that would be considered a self-dealing transaction), 
residual lawmaking rights should be allocated to courts, not left with legislatures. This does give courts substantial discretion. In fact, German legal scholars have raised the concern that courts might misuse the duty of loyalty by using their own judgment to assess the fairness of private transactions, rather than respecting the autonomous rights of private parties to decide this for themselves. ${ }^{47}$ This argument is flawed for several reasons. Mandatory statutory law does not better honor the private autonomy of corporate stakeholders. Moreover, bringing a case to court suggests that private parties were unable to agree on the meaning of the obligations they owe each other. The solution is not necessarily a court as a third party arbiter, but failing to provide dispute resolution mechanisms leaves conflicts to be resolved outside the law. Finally, the case law discussed suggests that courts used broad principles less to substitute the goals of the parties with their own than to correct for statutory law that left little autonomy to private parties.

\footnotetext{
${ }^{47}$ As Wellenhofer-Klein [2000 \#1399] put it, "upholding one party to the duty of loyalty always implies an interference with the private autonomy of that person" (at p. 588)
} 


\section{Part IV: Transplanting Fiduciary Duty}

The incompleteness of law has important implications for transplanting law from one system to another. Given that neither statutory nor case law will specify all relevant contingencies, the effectiveness of transplanted law depends on how the law will be understood, interpreted and ultimately applied by domestic institutions in the transplant country (Berkowitz, Pistor, and Richard 2002). In addition, the allocation of lawmaking and law enforcement rights to the proper agents - courts vs. regulators - becomes critical for the effectiveness of law, implying that the process of legal transplantation should be supported by institutional design and institutional reform. Obviously, this is a much more complex process than simply transplanting law. Legal institutions, such as the courts in Delaware, are the product of a long evolutionary process, and so is the law they produce along the way. As we have seen, other states in the United States have found it difficult to emulate this model. One can hardly expect that other countries with a very different legal history will do any better. If law was complete, the task would me much easier. Law would give clear guidance to social and economic actors as well as to law enforcers and thus should deter in transplant countries as effectively as in origin countries. The incompleteness of law is therefore an important element that can explain the transplant effect. Empirical evidence has shown that legal transplants are often rejected or ignored in the law receiving countries and thus have little direct impact on either court practice or behavior (Berkowitz, Pistor, and Richard 2002). The same pattern appears to countries irrespective of the origin of their legal systems, i.e. whether they belong to the common law, or one of the civil law families. 
Our theory would predict that the more incomplete the law is, the less effective the transplantation will be. The transplantation of open-ended concepts, such as fiduciary duty, therefore seems particularly difficult, because it cannot serve as a clear guidance for actual behavior or as an effective deterrent against violations. A response to this problem has been to favor "bright-line" rules over broad legal concepts in legal reform projects (Hay, Shleifer, and Vishny 1996)? Indeed, this insight is reflected in the Russian corporate law, which was drafted with the help of American legal experts who emphasized the educational function of corporate law and the importance of spelling out in much detail the procedural rights of shareholders in the corporate enterprise (Black and Kraakman 1996; Black, Kraakman, and Hay 1996). However, bright-line rules do not eliminate the incompleteness problem. While they do not pose the same problems of Type I incomplete law, such as fiduciary duty, they create the typical problems of Type II incomplete law. Bright line rules are relatively easy to draft, but are likely to over-deter since many actions are flatly prohibited may potentially be welfare enhancing. Another caveat is that they may be easily circumvented, implying that they may under-deter as well. This applies especially to highly specific rules that attempt to differentiate types of actions that shall be prohibited from those that are permissible. Moreover, bright line rules may limit the role courts play in applying and interpreting the law, in fact they are designed to limit the courts' power. This may be sensible in areas of the law where other institutions, such as regulators, could effectively enforce the law. Otherwise, a better solution might be to explicitly allocate lawmaking and law enforcement rights to courts and to encourage a process that could eventually lead to better, i.e. more complete, case law. 
To understand the above point better, recall the failure of civil law systems to allocate residual lawmaking rights to courts in the area of fiduciary duty. Whenever the law does not either explicitly or implicitly allocate residual lawmaking rights, individuals are the default holders of such rights. When disputes arise and different parties hold different views about the interpretation of their rights, the logical consequence of this allocation of lawmaking rights is dispute resolution outside the formal legal framework. While this outcome may be satisfactory in cases where one may count on the cooperation of the parties concerned, absent incentives to cooperate, the most likely outcome is that the party with greater de facto power prevails. In the corporate context of transition economies, this could be management, or controlling shareholders.

Giving courts residual lawmaking rights implies taking the risk that courts will arrive at solutions that may not be desirable from either an economic efficiency or social welfare standpoint. As noted above, lack of independence and impartiality of courts is an important explanation for why some legal systems have opted for restricting the courts' lawmaking rights. But this argument is only partly convincing. Courts are reactive, not proactive law enforcers meaning that courts get involved as arbiters only when a dispute is brought before them. The most likely response to courts that are corrupt or politicized is therefore less litigation, not excessive litigation with courts being instrumentalized for ulterior motives. Russian litigation data for commercial disputes in the first half of the 1990s suggests that this was indeed a wide spread response to a court system, whose trustworthiness was in doubt, not the least because of its roots in the socialist system (Pistor 1995a; Pistor 1996). In contrast to other transition economies, where litigation rates boomed after the onset of radical economic reforms, litigation rates in Russia 
declined by 30 percent annually in 1993 and 1994. Since 1995 the trend has been slowly reserved. By 2000, litigation rates had nearly doubled, ${ }^{48}$ suggesting a greater demand for the services courts may provide, the remaining problems of the Russian court system, including lack of regular payments of judges, inabilities to fill vacant posts, and allegations of corruption not withstanding (Murphy 1998). ${ }^{49}$

The reactive nature of court actions limits the scope for misuse, but does not rule out the possibility that courts may be used by some parties strategically. Some of the Russian case law discussed above could be interpreted as a strategic use of courts by companies wishing to escape contractual liability. Courts may be more volatile to such pressures when dealing with open-ended standards than when dealing with clearly specified rules. ${ }^{50}$ But this danger has to be weighed against the potential benefits of making a broader range of actions justiciable. The question that must be addressed is, if courts shall not do it, who will exercise the right to delineate the powers of corporate actors? A possible alternative to courts as holders of residual lawmaking and law enforcement rights are regulators. However, as we pointed out in Section 1 of this paper, regulators are not able to enforce the principle of fiduciary duty at reasonable cost. In fact, allocating residual lawmaking and law enforcement rights to them might lead to excessive state intervention.

Litigation has other benefits that both legislation and regulation are missing. As Hayek has pointed out, an important function of litigation is that weaknesses in existing law are revealed, which may be corrected by the legislature (Hayek 1973). While it may

\footnotetext{
${ }^{48}$ In 1992, the total number of disputes was around 380,000 cases. In 200,000 a total of 643,353 cases had been filed and 539,490 rulings were issued. See Court-statistics published by the SAC in Vestnik Vyshevo Arbitrazhnovo Suda 2001 \#4, pp. 12.

${ }^{49}$ Murphy's analysis applies to the courts of general jurisdiction. For a more positive assessment of the Russian Arbitrazh courts with jurisdiction over commercial affairs, see (Hendley 1999) and(Hendley 2001).
} 
possible for legislatures to collect information by other means, such as surveys (Kaplow 1997), the necessary signals to conduct a survey may not be received until much harm has been done. There is some indirect evidence for the role case law plays in the advancement of corporate law. During the decades that followed the first enactment of corporate statutes in England, the US, France and Germany, legislative change has been much more frequent in common law countries than in civil law countries (Pistor et al. 2001). This suggests that case law holds important information for legislature and triggers quicker intervention than the regular legislative process.

If there is no good alternative to courts in handling actions that may violate fiduciary duties, then the question arises, if and how courts in civil law countries could be induced to play a more active role in enforcing fiduciary principles. Just changing statutory law may not do the trick. In addition, procedural rules have to be adapted so that minority shareholders have standing in court and can litigate at reasonable cost. Take the example of recent legal changes in Japan, a country that is usually classified as a German civil law system, but that received U.S. style corporate law in 1950. Despite the infusion of AngloAmerican law, courts continued to play only a minor role in enforcing shareholder rights. While this has often been attributed to cultural factors, changes in procedural rules governing litigation costs resulted in a flood of derivative suits. Thus, it appears that institutional obstacles rather than culture prevented litigation prior to these changes (West $2001)^{51}$

\footnotetext{
${ }^{50}$ In this sense, the narrow wording of the conflict of interest rules might be regarded as a effective limits and discretionary court power.

${ }^{51}$ Whether or not derivative actions actually result in better case law on fiduciary duty, or even more broadly, leads to improvements in corporate governance, is quite a different matter. See [West, 2001 \#1382] and (Romano 1991) for a critical account of the economic rational for litigation.
} 
Still, our survey of the emerging case law in transition economies suggests that procedural rules may not be sufficient. As long as first instance courts continue to stick to the letter of the law, they may discourage litigation. Thus, the law should explicitly allocate residual lawmaking rights to them. Open ended, broad standards, such as fiduciary duty, or "diligent trader" will not suffice to motivate private agents to bring a case, or to induce courts to use a case for residual lawmaking. Instead, the law could enumerate typical actions that might be considered as a violation of fiduciary duty principles, but add explicitly that other, similar actions, should be treated by courts in the same manner. Courts would have to develop case law that distinguishes actions that fit within this category from those that don't. The scope of the residual lawmaking rights would be much more focused, enabling disgruntled parties to pin point misjudgment in appeal processes.

None of the above suggests that courts in civil law countries will produce the same solutions as common law judges in the U.K. or the U.S. In fact, allocating lawmaking rights to courts is likely result in greater divergence rather than convergence of the law, as judges will respond to cases brought before them, which are bound to differ from cases litigated elsewhere.

\section{Conclusion}

The major proposition of this paper is that courts should hold residual lawmaking rights with regards to actions that may violate the principle of fiduciary duty. The principle of fiduciary duty exemplifies Type I incomplete law. It is broad and 
ambiguously stated. The very nature of the actions that are governed by this principle make it impossible to right a highly specific law. Where lawmakers have attempted to do so, they have usually carved out only a subset of conflict of interest provisions, but have not been able to replicate the reach of the fiduciary duty principle as enforced by courts. Regulators may be superior to courts in enforcing financial market regulation, given that it is easier to standardize the type of action the law seeks to prevent, but they are hardly a solution to the problem of enforcing broad principles of corporate conduct. Courts as residual lawmakers benefit from their function as reactive law enforcers. They are called upon to make law when critical information is revealed in the process of litigation and therefore have the specific facts at hand when issuing their ruling.

We do not claim that courts can produce complete law. Courts, just as legislatures or regulators, cannot foresee all future contingencies. But they can solve a case brought to the attention to the court, even when statutory and past case law is incomplete. Their function is to adapt the law in light of specific cases and thus enhance its completeness, and ultimately its deterrence effect. Greater certainty about the residual lawmaking function of courts is likely to increase litigation (all else being equal), which will result in a more comprehensive - and thus more complete - body of case law.

In transition economies, courts may not yet be in a position to play an effective role in developing norms for corporate conduct. The scarcity of cases that have made it to the courts so far can be taken as an indicator that there is little demand for their actions. However, the lack of litigation in this area may well lie in the uncertainty about the courts' residual lawmaking rights and the lack of clear procedural rules to support litigation. Remarkably, Russia has seen probably the largest number of cases among 
transition economies on conflict of interest problems. Perhaps it has also experienced the most extensive violation of shareholder rights. An alternative explanation is that by explicitly regulating conflict of interest matters in statutory law and referring the solution of these matters to courts, the legislature confirmed that these issues were justiciable. The main function of these provisions was thus to encourage litigation by allocating residual lawmaking rights to courts. This does not mean that the law was optimal, i.e. that it has solved all relevant issues. But the fact that private parties have responded to an explicit allocation of residual lawmaking rights is encouraging. At the same time, it is worth noting that where the scope of the courts' residual lawmaking rights was too broad, litigation has not occurred.

When called to duty, lower level Russian courts have shown to be reluctant to seize the opportunity and develop into more active residual lawmakers. Still, the SAC has indicated that it is not satisfied with highly literal interpretations and has already begun to guide lower level courts not to take an overtly literal interpretation of the law. To be sure, the decisions of the SAC have not all been consistent or entirely convincing. However, we would argue that this is part of the process of residual lawmaking. In fact, closer inspection of early English case law exemplifies the process of trial and error it takes to establish a consistent body of case law over time.

In sum, the Anglo-American concept of fiduciary duty may not be easy transplantable either to civil law systems or to transition economies. However, an important insight that may be gained from the history of this concept in Anglo-American law is that a broad concept combined with allocating residual lawmaking rights to courts may be the most effective way to deal with issues that escape close legal regulation. 
When given explicit residual lawmaking rights, courts in civil law jurisdictions might well develop a body of case law that will be of some guidance in the future. Not allocating courts residual lawmaking rights to courts may be counter productive, as this will relief courts from the responsibility of developing a body of case law, without a better alternative for making law in this area at hand. 


\section{$\underline{\text { References }}$}

Arsht, Samuel S. 1976. A History of Delaware Corporation Law. Delaware Journal of Corporate Law 1 (1):1-22.

Becker, Gary S. 1968. Crime and Punishment: An Economic Approach. Journal of Political Economy 76:169-217.

Berkowitz, Dan, Katharina Pistor, and Jean-Francois Richard. 2002. Econmic Development, Legality, and the Transplant Effect. European Economic Review ((forthcoming)).

Bernstein, Lisa. 1992. Opting out of the Legal System: Extralegal Contractual Relations in the Diamond Industry. Journal of Legal Studies 21 (1):115-157.

Black, Bernard. 2001. The Fiduciary Duty of Outside Directors. Stanford: John M. Olin Program in Law and Economics.

Black, Bernard, and Reinier Kraakman. 1996. A Self-Enforcing Model of Corporate Law. Harvard Law Review 109:1911-1982.

Black, Bernard, Reinier Kraakman, and Jonathan Hay. 1996. Corporate Law from Scratch. In Corporate Governance in Eastern Europe and Russia, edited by R. Frydman, C. W. Gray and A. Rapaczynski. Budapest, London, New York: Central European University Press.

Black, Bernard, Reinier Kraakman, and Anna Tarassova. 2000. Russian Privatization and Corporate Governance: What Went Wrong? Stanford Law Review 52:1731-1803.

Black, Bernard S., Reinier Kraakman, and Anna S. Tarassova. 1998. Guide to the Russian Law on Joint Stock Companies. The Hague, London, Boston: Kluwer Law International.

Breidenbach, Stephan, ed. 2001. Handbuch Wirtschaft und Recht in Osteuropa. München: C.H. Beck.

Butler, William E. 1988. Soviet Law. 2 ed. London: Butterworths.

Cary, William L. 1976. Federalism and Corporate Law: Reflections upon Delaware. Yale Law Journal 83:663.

Charny, David. 1990. Nonlegal Sanctions in Commercial Relationships. Harvard Law Review 104:373.

Clark, Robert Charles. 1986. Corporate Law. Boston

Toronto: Little, Brown \& Company.

Coffee, John C., Jr. 1989. The Mandatory/Enabling Balance in Corporate Law: An Essay on the Judicial Role. Columbia Law Review 89:1618-1691.

Cooter, Robert. 1996. Decentralized Law for a Complex Economy: The Structural Approach to Adjudicating the New Law Merchant. University of Pennsylvania Law Review 144 (5):1643-1696.

Daines, Robert. 2001. Does Delaware Law Improve Firm Value? Journal of Financial Economics 62 (3):525-558.

Dreher, Meinrad. 1993. Treuepflichten zwischen Aktion'ren und Verhaltenspflichten bei der Stimmrechtsbündelung. Zeitschrift für das gesamte Handelsrecht 157:150171.

Eisenberg, Melvin Aron. 2000. Corporations and Other Business Organizations. 8 ed. New York, NY: Foundation Press. 
Ellickson, Robert C. 1991. Order Without Law - How Neighbors Settle Disputes. Cambridge, Ma: Harvard University Press.

Fisch, Jill E. 2000. The Peculiar Role of the Delaware Courts in the Competitoin for Corporate Charters. ssrn.com.

Ginsburg, Jane C. 1996. Legal Methods - Cases and Materials. Westbury, New York: The Foundation Press, Inc.

Glaeser, Edward, Simon Johnson, and Andrei Shleifer. 2001. Coase vs. Coasians. Quarterly Journal of Econmics 116 (3):853-899.

Glendon, Mary Ann, Michael W. Gordon, and Christopher Osakwe. 1994. Comparative Legal Traditions: Text, Material and Cases on the Civil and Common Law Traditions, with Special References to French, German, and English. St. Paul, Minn.: West.

Goshen, Zohar. 2001. Voting and the Economics of Corporate Self-Dealing: Theory Meets Reality. forthcoming.

Hart, H.L.A. 1961. The Concept of Law. Oxford: Oxford University Press.

Hay, Jonathan R., Andrei Shleifer, and Robert W. Vishny. 1996. Toward a Theory of Legal Reform. European Economic Review 40 (3-5):559-567.

Hayek, Friedrich A. 1973. Law, Legislation and Liberty - Rules and Order. Vol. 1. Chicago: University of Chicago Press.

Hendley, Kathryn. 1999. Rewriting the Rules of the Game in Russia: The Neglected Issue of the Demand for Law. East European Constitutional Review 8 (4):89-95.

Hendley, Kathryn. 2001. Beyond the Tip of the Iceberg: Business Disputes in Russia. In The Value of Law in Transition Economies, edited by P. Murell. Ann Arbor: University of Michigan Press.

Hopt, Klaus J., and Herbert Wiedemann, eds. 1992. Aktiengesetz: Großkommentar. 4 ed, Großkommentare der Praxis. Berlin, New York: Walter de Gruyter.

Hueffer, Uwe. 1995. Aktiengesetz. 2 ed. München: C.H. Beck'sche Verlagsbuchhandlung. Hüffer, Uwe. 1990. Zur gesellschaftsrechtlichen Treupflicht als richterrechtliche Generalklausel. In Festschrift für Ernst Steindorff zum 70. Geburtstag, edited by J. F. Baur, K. J. Hopt and K. P. Mailänder. Berlin, New York: Walter de Gruyter.

Johnson, Simon, Rafael La Porta, Florencio Lopez-de-Silanes, and Andrei Shleifer. 2000. Tunneling. American Economic Review 90 (2):22-27.

Kaplow, Louis. 1992. Rules versus Standards: An Economic Analysis. Duke Law Journal 42:557-629.

Kaplow, Louis. 1997. General Characteristics of Rules. In http//encyclo.findlaw.com/lit/9000art.html.

Komesar, Neil. 2001. The Limits of Law. Cambridge: Cambridge University Press.

Kursynsky-Singer, Eugenia. 1999. Das Aktienrecht in der Rechtsprechung des rußländischen Obersten Arbitragegerichts. WGO Monatshefte für Osteuropäeisches Recht 41 (6):423-438.

La Porta, Rafael, Florencio Lopez-de-Silanes, Andrei Shleifer, and Robert Vishny. 1999. The Quality of Government. The Journal of Law, Economics \& Organization 15 (1):222-283.

La Porta, Rafael, Florencio Lopez-de-Silanes, Andrei Shleifer, and Robert W. Vishny. 1997. Legal Determinants of External Finance. Journal of Finance LII (3):11311150. 
La Porta, Rafael, Florencio Lopez-de-Silanes, Andrei Shleifer, and Robert W. Vishny. 1998. Law and Finance. Journal of Political Economy 106 (6):1113-1155.

Larcom, Russel Carpenter. 1937. The Delaware Corporation. Baltimore: John Hopkins Press.

Mahoney, Paul. 2001. The Common Law and Economic Growth: Hayek Might be Right. Journal of Legal Studies.

Murphy, Patrick. 1998. The Russian Courts of General Jurisdiction: In Crisis, Undergoing Reform, or Both? The Parker School Journal of East European Law 4 (2):207-224.

Pistor, Katharina. 1995a. Law Meets the Market: Matches and Mismatches in Transition Economies. Washington, D.C.: The World Bank.

Pistor, Katharina. 1995b. Privatization and Corporate Governance in Russia: An Empirical Study. In Privatization, Conversion and Enterprise Reform in Russia., edited by M. McFaul and T. Pelmutter. Boulder, Co: Westview Press.

Pistor, Katharina. 1996. Supply and Demand for Contract Enforcement in Russia: Courts, Arbitration, and Private Enforcement. Review of Central and East European Law $22(1): 55-87$.

Pistor, Katharina. 2000a. The Evolution of Legal Institutions and Economic Regime Change. In Governance, Equity and Global Markets - Proceedings of teh Annual Bank Converence on Development Economics in Europe, edited by B. Pleskovic, G. Garcia, F. Bourguignon and J. Pisani-Ferry. Paris: La documentation Francaise.

Pistor, Katharina. 2000b. Patterns of Legal Change: Shareholder and Creditor Rights in Transition Economies. European Business Organization Law Review 1 (1):59110.

Pistor, Katharina, Yoram Keinan, Jan Kleinheisterkamp, and Mark West. 2001. The Evolution of Corporate Law. submitted for publication.

Pistor, Katharina, and Chenggang Xu. 2002a. Incomplete of Law: A Conceptual and Analytical Framework - Its Application to Financial Market Regulation. unpublished mimeo Columbia Law School.

Pistor, Katharina, and Chenggang Xu. 2002b. Law Enforcement under Incomplete Law. unpublished mimeo.

Polinsky, Mitchell, and Steven Shavell. 2000. The Economic Theory of Public Enforcement of Law. Journal of Economic Literature 38 (1):45-76.

Priest, George L. , and Benjamin Klein. 1984. The Selection of Disputes for Litigation. Journal of Legal Studies 13 (January):1-55.

Rock, Edward B., and Michael Wachter. 2001. Norms and Corporate Law. University of Pennsylvania Law Review 149 (6):1607-1618.

Romano, Roberta. 1991. The Shareholder Suit: Litigation Without Foundation? Journal of Law, Economics, \& Organization Spring 7:55-87.

Shleifer, Andrei, and Robert W. Vishny. 1997. A Survey of Corporate Governance. The Journal of Finance LII (2):737-783.

Solum, Lawrence B. 1999. Indeterminacy. In A Companion to Philosophy of Law and Legal Theory, edited by D. Patterson. Malden, MA: Blackwell Publishers Ltd.

Stigler, George J. 1970. The Optimal Enforcement of Laws. Journal of Political Economy 78 (3):56-536. 
Timm, Wolfram. 1991. Treuepflichten im Aktienrecht. WM 45 (12):481.

Wellenhofer-Klein, Marina. 2000. Treupflichten im Handels-, Gesellschafts- und Arbeitsrecht. Rabelszeitschrift 64:564-594.

West, Mark. 2001. Why Shareholders Sue:The Evidence from Japan. Journal of Legal Studies 30:351.

Zweigert, Konrad, and Hein Kötz. 1998. Introduction to Comparative Law. Oxford: Clarendon Press. 